\title{
Planning of Land Use Based on Environmental Carrying Capacity in East Tidore Subdistrict, Tidore Island City
}

\author{
Ramli Hadun ${ }^{1, *}$, Amiruddin Teapon ${ }^{2}$ \\ ${ }^{1}$ Agriculture Studies Program, Postgraduate at Universitas Khairun, Ternate, Indonesia \\ ${ }^{2}$ Soil Science Study Program, Faculty of Agriculture, Universitas Khairun, Ternate, Indonesia \\ "Corresponding author.Email: ramlihadun70@gmail.com,ramlihadun@ymail.com
}

\begin{abstract}
Land needs for the development of the agricultural sector in East Tidore Subdistrict always increase along with the increasing population. Lack of understanding of land characteristics causes agricultural development is not based on the ability and carrying capacity of land. This can be seen from the increasingly widespread development of agriculture on steeply sloped forest lands $(>45 \%)$ that have the potential to cause land damage. In order that that land can be used in an optimal, continual and sustainable manner, planning of land use is needed based on the capability and carrying capacity of the land. This research aims to evaluate the suitability of land use, determine the status of carrying capacity of land and determine the direction of land use based on the ability and carrying capacity of the environment in East Tidore Subdistrict. This research uses an analytical approach with free survey observation distance (free survey) combined with transects and boring observation types and pit profiles. The results of the research obtained six land capability classes in East Tidore Subdistrict, namely class III covering 650.2 ha $(21.5 \%)$, class IV covering $1,060.8$ ha (35.1\%), class V covering 47.2 ha (1.6\%), class VI covering 454.1 ha $(15.0 \%)$, class VII covering 325.7 ha (10.8\%) and class VIII covering 481.2 ha (15.9\%). Land capability classes suitable for agricultural development (classes III and IV) are 1,711.0 ha (56.7\%) and inappropriate (classes V, VI, VII and VIII) are 1,308.2 ha (43.3\%). The use of existing agricultural plantations/mixed estates that are in accordance with the capability of land (class III and IV) covering $1,176.4$ ha $(39.0 \%)$ and not suitable (class V, VI, VII and VIII) covering 860.1 ha $(28.5 \%)$, and the use of suitable moor/land area of 24.3 ha $(0.8 \%)$ and unsuitable area of 28.9 ha $(1.0 \%)$. The availability of land (SL) covers an area of 2,926 ha and the need for land equivalent to rice (DL) is 6,420 ha, where the land requirement has exceeded the carrying capacity of the land contained in East Tidore Subdistrict. The direction of land use for agricultural development in the Subdistrict of East Tidore covering an area of $2,300.1$ ha $(76.2 \%)$ consisting of the use of moor/land area of 7.8 ha $(0.3 \%)$, mixed gardens covering $1,058.7$ ha (35.1\%) and agroforestry covering 1,233.6 ha (40.9\%).
\end{abstract}

Keywords: land capability, suitability of land use, environmental carrying capacity

\section{INTRODUCTION}

The challenge of sustainable management of natural resources is how to maintain a balance between meeting the needs of human life and the sustainable use of natural resources and environmental services for humans. The sustainable use of natural resources is a process to create sustainable use and preservation of natural resources, the direction of investment in the use of natural resources and institutional changes related to the utilization and preservation of natural resources are consistent with current and future utilization targets $[1,2]$. Natural resources in the context of land are basically limited in terms of area and productivity $[3,4]$. On the other hand increasing population, increasing living standards and regional economic development requires an increase in land use. Without rational consideration, land use activities are often carried out not in accordance with the capabilities and carrying capacity of land, which in turn has an impact on damage (degradation) and scarcity of land resources.

According to [5] that the carrying capacity and sustainability of land and water natural resources is largely determined by the interaction between the way humans manage natural resources and the role of biophysical environmental factors. If land use exceeds the limits of the 
ability of the land concerned without the existence of conservation technology efforts, it can lead to the occurrence of critical land that is not productive. This is increasingly worrying about land use practices taking place in watersheds, resulting in high levels of $\mathrm{mud} /$ sedimentation due to erosion.

Sustainable and sustainable use of land is achieved if carried out in accordance with the capabilities of the land and the carrying capacity of the land. Land capability is basically the capacity of land to support a kind or type of land use that is developed. Each class of land capability reflects the nature or characteristics of a particular land, the ability of production or land productivity, management requirements and the threat of damage if the land is used for a land use [6-8]. While the carrying capacity of land is the ability of an environment to support life. Carrying capacity of land is related to the area and productivity of land needed to meet the needs of human life in an area.

Land requirements for the agricultural sector in East Tidore Subdistrict always increase along with increasing population. Lack of understanding of land characteristics causes agricultural development is not based on the ability and carrying capacity of land. This can be seen from the increasingly widespread development of agriculture on steeply sloped forest lands $(>45 \%)$ that have the potential to cause land damage. The expansion of land for agriculture in East Tidore Subdistrict in 2012 has reached $1,124.5$ ha $(37.0 \%)$ and the separated forest area is 447.6 ha $(14.7 \%)$. If the condition of the utilization of land resources is not considered and considered early, in the future there will be a scarcity of land resources. Scarcity of land resources reduces the productivity and quality of the environment.

Efforts to use land in East Tidore Subdistrict optimally, sustainably and sustainably require land use planning based on the capability and carrying capacity of the land.

This research aims to: 1). evaluate suitability for land use, 2 ). determine the carrying capacity of land and 3 ). determine the direction of land use based on the ability and carrying capacity of the environment in East Tidore Subdistrict. This research is useful in providing data and information regarding land capability and land use suitability for agricultural development in East Tidore Subdistrict and as input for local governments in land use planning based on land carrying capacity.

\section{METHODS}

This research was conducted in East Tidore Subdistrict, Tidore Kepulauan City, which lasted from June to November 2018 and analyzed soil at the Soil Chemical and Fertility Laboratory, Soil Department, Faculty of Agriculture, Universitas Hasanuddin, Makassar.

The material used in this research is soil samples from the field and aquades, while the equipment used is GPS (global position system), clinometer, altimeter, soil color book (muncel soil color cart), pin nails, roomy knives, meter rollers, steel meters, Belgium type boring, sample rings, digital cameras, plastic bags, label papers, profile description cards, computer and ArcGIS software version 10.2 and scale 1 work map: 30,000 and writing stationery. This research uses an analytical approach with free survey observation distance (free survey) combined with transects and soil identification using boring and profile techniques. The number of land units observed was 34 land units and the number of soil samples analyzed was 21 soil samples. Data analysis includes analysis of land capability, suitability of land use, carrying capacity of land and direction of land use. Land capability analysis uses the limiting factor method in which the land capability class is determined by the heaviest land boundary or land boundary which is at a minimum condition. Land capability classification refers to the land capability classification system of the United States Department of Agriculture (USDA) as stated in Agricultural Handbook No.210 [6]. The criteria for classifying land capability are in Table 1 .

Analysis of land use suitability aims to determine the suitability of existing land use with land capability classes [1-2], [9-10]. The analysis process is by overlapping between land use maps and land capability maps. The analysis of the carrying capacity of the environment refers to the Regulation of the Minister of Environment No. 17 of 2009 [11] concerning Guidelines for the Determination of the Supporting Capacity of the Environment in Regional Spatial Planning. The carrying capacity of the environment is obtained based on the comparison between the availability (SL) and land requirements (DL), with the criteria for carrying capacity of land as follows:

If $\mathrm{SL}>\mathrm{DL}$, the carrying capacity of the land is declared surplus.

If $\mathrm{SL}<\mathrm{DL}$, carrying capacity is declared deficit or exceeded.

The direction of land use in East Tidore Subdistrict is based on the results of the analysis of land capability, existing land use, land use suitability and forest area functions. 


\section{RESULTS AND DISCUSSION}

\section{A. Land Biophysics}

Biophysical land that plays an important role in determining the ability of land use in East Tidore Subdistrict includes climate, soil, topography, and land cover. Climatic conditions based on the Schmidth and Ferguson climate classification system in Handoko [13] classified as wet climate (B) with an average dry month $(\mathrm{Bk}<60 \mathrm{~mm})$ of \pm 2 months and a wet month $(\mathrm{Bb}>100$ $\mathrm{mm}$ ) of \pm 9 months and a $\mathrm{Q}$ value of $21.7 \%$. Annual rainfall is $2,247.3 \mathrm{~mm} /$ year, the average temperature is $27.0^{\circ} \mathrm{C}$ and the average humidity is $82.1 \%$.

The topography varies between flat $(0-3 \%)$ to very steep $(>65 \%)$. The topography suitable for agricultural development is between flat $(0-3 \%)$ to sloping topography $(15-30 \%)$ with an area of $1,758.2$ ha $(58.2 \%)$, while the topography that is less suitable for agricultural development is quite steep (30-45\%) to very steep ( $>65 \%)$ there are $1,261.0$ ha $(41.8 \%)$.

Table 1. Criteria for land capability classification

\begin{tabular}{|c|c|c|c|c|c|c|c|c|c|}
\hline \multirow{2}{*}{ No. } & \multirow{2}{*}{ Limiting factor } & \multicolumn{8}{|c|}{ Land Ability Class } \\
\hline & & I & II & III & IV & $\mathbf{V}$ & VI & VII & VIII \\
\hline 1 & Slope & Lo & L1 & L2 & L3 & Lo & L4 & L5 & L6 \\
\hline 2 & Texture & & & & & & & & \\
\hline & - Upper layer & $\mathrm{t} 2, \mathrm{t} 3$ & $\mathrm{t} 1, \mathrm{t} 4$ & $\mathrm{t} 1, \mathrm{t} 4$ & $(*)$ & $(*)$ & $(*)$ & $(*)$ & t5 \\
\hline & - Bottom layer & $\mathrm{t} 2, \mathrm{t} 4$ & $\mathrm{t} 2, \mathrm{t} 4$ & $\mathrm{t} 2, \mathrm{t} 4$ & $(*)$ & $(*)$ & $(*)$ & $(*)$ & t5 \\
\hline 3 & Land drainage & do,d1 & $\mathrm{d} 2$ & d3 & $\mathrm{d} 4$ & $(* *)$ & $(*)$ & $(*)$ & $(*)$ \\
\hline 4 & Permeability $^{1}$ & P2,P3 & P2,P3 & $\mathrm{P} 2, \mathrm{P} 3, \mathrm{P} 4$ & P2,P3,P4 & $\mathrm{P} 1$ & $(*)$ & $(*)$ & P5 \\
\hline 5 & Depth & ko & ko & $\mathrm{k} 1$ & $\mathrm{k} 2$ & $(*)$ & $\mathrm{k} 3$ & $(*)$ & $(*)$ \\
\hline 6 & Erosion sensitivity $^{1}$ & KE1,KE2 & KE3 & KE4,KE5 & KE6 & $(*)$ & $(*)$ & $(*)$ & $(*)$ \\
\hline 7 & Rate of erosion & eo & e1 & $\mathrm{e} 2$ & e3 & $(*)$ & $\mathrm{e} 4$ & e5 & $(*)$ \\
\hline 8 & Rock/outcrop & bo & bo & b1 & b2 & b3 & $(*)$ & $(*)$ & b4 \\
\hline 9 & Flood threat & Oo & $\mathrm{O} 1$ & $\mathrm{O} 2$ & $\mathrm{O} 3$ & $\mathrm{O} 4$ & $(*)$ & $(*)$ & $(*)$ \\
\hline 10 & Salinity $(* * *)^{1}$ & Go & g1 & g2 & g3 & $(* *)$ & g3 & $(*)$ & $(*)$ \\
\hline
\end{tabular}

Description: $\mathrm{L}=$ slope, $\mathrm{t}=$ texture, $\mathrm{d}=$ soil drainage, $\mathrm{P}=$ permeability, $\mathrm{k}=\mathrm{depth}, \mathrm{KE}=$ erosion sensitivity, $\mathrm{e}=$ level of erosion,

$\mathrm{b}=$ rock/outcrop, $\mathrm{O}=$ flood threat, $\mathrm{g}=$ salinity, $(*)=$ it can have any limiting factor, $(* *)=$ not applicable, $(* * *)=$ specifically dry climate areas

Soil conditions according to the USDA classification system [14] and its equivalent to PPT [15] there is one order of land namely Inceptisols (Kambisol and Gleisol). The order of the Inseptisols is divided into sub orders aquepts and udepts. The aquepts subsoil produces the Endoaquepts soil group and further produces the Typic Endoaquepts subgroup. Suborder udepts produce Dystrudepts soil groups based on morphological, physical and chemical properties of soil divided into four soil subgroups namely Lithic Dystrudepts, Typic Humudepts, Typic Dystrudepts and Vitrandic Humudepts.

The dominant land use is mixed gardens with a total area of 2,036.5 ha (67.5\%). Mixed estate land uses planted with annual crops include coconut, clove and nutmeg. While the use/closure of remaining forest land includes secondary forest covering 348.0 ha $(11.5 \%)$, swamp/sago forest covering 32.3 ha $(1.1 \%)$ and mangrove forest covering 10.8 ha $(0.4 \%)$. The extent of types of land use based on the results of the mapping are shown in Table 2.

Table 2. Extensive use/closure of land in East Tidore Subdistrict

\begin{tabular}{|c|l|r|r|}
\hline \multirow{2}{*}{ No } & \multicolumn{1}{|c|}{ Land Use/Closure } & \multicolumn{1}{c|}{ Ha } & \multicolumn{1}{c|}{ \% } \\
\cline { 3 - 4 } & & 191.8 & 6.4 \\
2 & Settlement & 53.2 & 1.8 \\
3 & Moor/Field & $2,036.5$ & 67.5 \\
4 & Plantation/Mixed garden & 13.3 & 0.4 \\
5 & Open land & 333.3 & 11.0 \\
6 & Shrubs & 10.8 & 0.4 \\
7 & Mangrove forest & 32.3 & 1.1 \\
8 & Swamp Forest & 348.0 & 11.5 \\
\hline \multicolumn{2}{|c|}{ Total } & $\mathbf{3 , 0 1 9 . 2}$ & $\mathbf{1 0 0 . 0}$ \\
\hline
\end{tabular}


Table 3. Land capability classification in East Tidore Subdistrict

\begin{tabular}{|c|c|c|c|c|}
\hline \multirow{2}{*}{ SPL } & \multirow{2}{*}{$\begin{array}{c}\text { Land Capability } \\
\text { Unit }\end{array}$} & \multirow{2}{*}{ Limiting Factor } & \multicolumn{2}{|c|}{ Width } \\
\hline & & & $\mathbf{H a}$ & $\%$ \\
\hline $12,17,22$ & IIIKE4 & Erosion sensitivity is quite high & 391.6 & 13.0 \\
\hline 23 & $\begin{array}{l}\text { IIIL2.KE4. } \\
\text { b1 }\end{array}$ & $\begin{array}{l}\text { Slope is slightly tilted }(8-15 \%) \text {, erosion sensitivity is rather } \\
\text { high and the amount of rock is small }\end{array}$ & 26.6 & 0.9 \\
\hline 14 & IIIL2.e2 & Slope is slightly tilted ( $8-15 \%$ and mild erosion rate) & 231.9 & 7.7 \\
\hline 2 & IVd4.o3 & Drainage is obstructed and the threat of frequent flooding & 83.2 & 2.8 \\
\hline 3.20 & IVP1 & Soil permeability is slow & 392.3 & 13.0 \\
\hline 11.13 & IVk2.b2 & Shallow soil depth and moderate amount of rock & 157.1 & 5.2 \\
\hline $5,24,25$ & IVL3 & Tilted slope $(15-30 \%)$ & 179.3 & 5.9 \\
\hline 8 & IVL3.P1 & Tilted slope (15-30\%) and medium soil permeability & 168.0 & 5.6 \\
\hline 15 & IVL3.e3.b2 & $\begin{array}{l}\text { Tilted slope }(15-30 \%) \text {, moderate erosion rate and moderate } \\
\text { amount of rock }\end{array}$ & 80.8 & 2.7 \\
\hline 1 & Vd5.04 & $\begin{array}{l}\text { Drainage is very obstructed, the threat of flooding is very } \\
\text { frequent }\end{array}$ & 14.3 & 0.5 \\
\hline 21.34 & Vb3 & Amount of many rocks & 32.9 & 1.1 \\
\hline 6.27 & VIL4 & Slope is rather steep $(30-45 \%)$ & 77.0 & 2.6 \\
\hline $9,18,28$ & VIL4.e4 & Slope is rather steep $(30-45 \%$, heavy erosion rate & 343.4 & 11.4 \\
\hline 26 & VIL4.k3.e4 & $\begin{array}{l}\text { Slope is rather steep }(30-45 \%) \text {, soil depth is very shallow } \\
\text { and the level of erosion is heavy }\end{array}$ & 33.8 & 1.1 \\
\hline $\begin{array}{c}10,16,29, \\
30.31\end{array}$ & VIIL5 & Slope is steep $(45-65 \%)$ & 316.4 & 10.5 \\
\hline 19 & VIIL5.e5 & Slope is steep $(45-65 \%)$, heavy erosion rate & 9.2 & 0.3 \\
\hline $4,7,32.33$ & VIIIL6 & Slope is very steep $(>65 \%)$ & 481.2 & 15.9 \\
\hline & & Total & $3,019.2$ & 100 \\
\hline
\end{tabular}

Source: Analysis and mapping results in 2017

Note: $\mathrm{d}=$ soil drainage, $\mathrm{KE}=$ erosion sensitivity, $\mathrm{e}=$ soil erosion, $\mathrm{L}=$ slope, $\mathrm{k}=$ soil depth, $\mathrm{t}=$ soil texture,

$\mathrm{b}=$ surface rock and $\mathrm{o}=$ flood/inundation threat

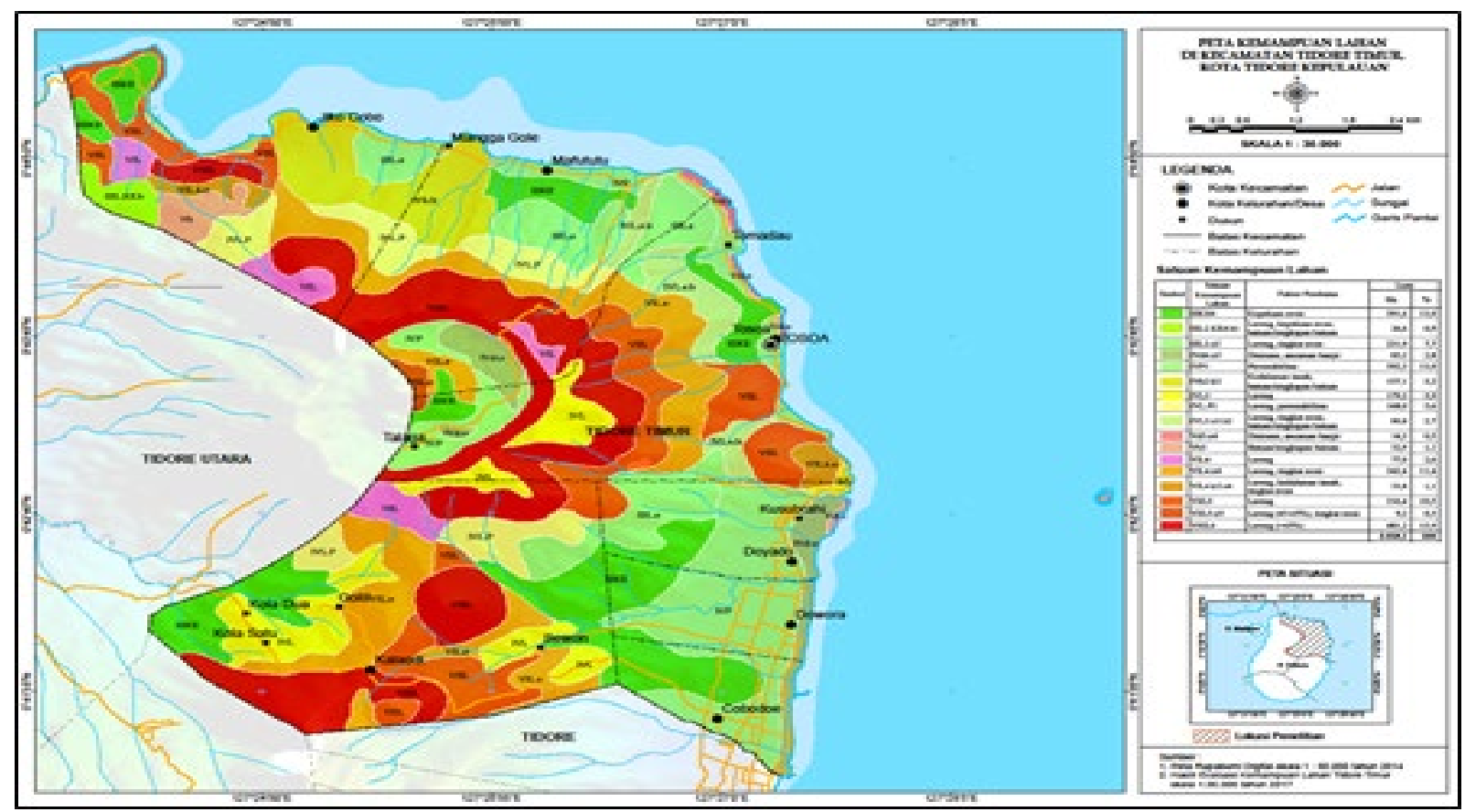

Figure 2. Land Capability Map in East Tidore Subdistrict 


\section{B. Land Capability Evaluation}

It is obtained that land capability in East Tidore Subdistrict based on the evaluation results is by six land capability classes namely class III covering 650.2 ha $(21.5 \%)$, class IV covering $1,060.8$ ha $(35.1 \%)$, class $V$ covering 47.2 ha $(1.6 \%)$, class VI covering 454.1 ha $(15.0 \%)$, class VII covering 325.7 ha $(10.8 \%)$ and class VIII covering 481.2 ha $(15.9 \%)$. The ability of land which is wide in East Tidore Subdistrict is class IV that is equal to $35.1 \%$. Detailed results of the capability evaluation are in Table 3 . Land capability classes in East Tidore Subdistrict suitable for medium to limited intensity agricultural development especially class III and IV with a total area of 1,711.0 ha $(56.7 \%)$ and less suitable for agricultural development namely classes V, VI, VII and VIII covering an area of $1,308.2$ ha $(43.3 \%)$. Spatial distribution of land capability is presented in Figure 2.

\section{Suitability of Land Use}

Land use suitability in Tidore Islands City based on the result of overlapping between the existing land use map and the land capability map obtained from the existing mixed land use in accordance with the capability of land (class III and IV) covering $1,176.4$ ha $(39.0 \%)$ and inappropriate (class V, VI, VII and VIII) covering 860.1 ha $(28.5 \%)$. The use of moor/fields in accordance with the capability of land area of 24.3 ha $(0.8 \%)$ and not in accordance with the area of 28.9 ha $(1.0 \%)$, and the use of settlement land which is in accordance with the capability of land with an area of 182.2 ha $(6.0 \%)$ and incompatible with an area of 9.6 ha $(0.3 \%)$.

\section{Land Carrying Capacity Analysis}

This analysis refers to Permen (Ministerial Regulation) LH No. 17 of 2009 [11] by comparing the parameters of land availability and needs. The parameters of land availability use the value of crop and livestock production, local rice productivity, unit price of rice $/ \mathrm{kg}$. Rice production in the City of Tidore Islands includes 2.5 tons $/ \mathrm{ha}(2,500 \mathrm{~kg} / \mathrm{ha})$ and 2.02 tons $/$ ha $(2,020 \mathrm{~kg} / \mathrm{ha})$ with an average rice production (lowland rice+upland rice) of 2.26 tons/ha $(2,260 \mathrm{~kg} / \mathrm{ha})$. Rice production is converted into rice with a rendition of 0.6274 , an average rice productivity of 1.418 tons/ha or $1,418 \mathrm{~kg} / \mathrm{ha}$ is obtained. The price of rice per kilogram in the City of Tidore Islands is Rp12,000. The value of crop and livestock production results of the analysis are in Table 4.

Land availability (SL) is obtained from the production value (IDR 49,789,530,000)/unit price of rice per kilogram (IDR 12,000$) \times 1 / 1,418 \mathrm{~kg} /$ ha obtained by the availability of land by 2,926 ha.

While the need for rice equivalent land (DL) uses the parameters of the population $(\mathrm{N})$ and the area of land needed for the needs of decent living per population (KHLL). The population (N) in East Tidore Subdistrict in 2016 reached 9,172 people with a growth rate of $2.12 \%$. The projected population for the next 10 years (2026) will reach 11,313 people.

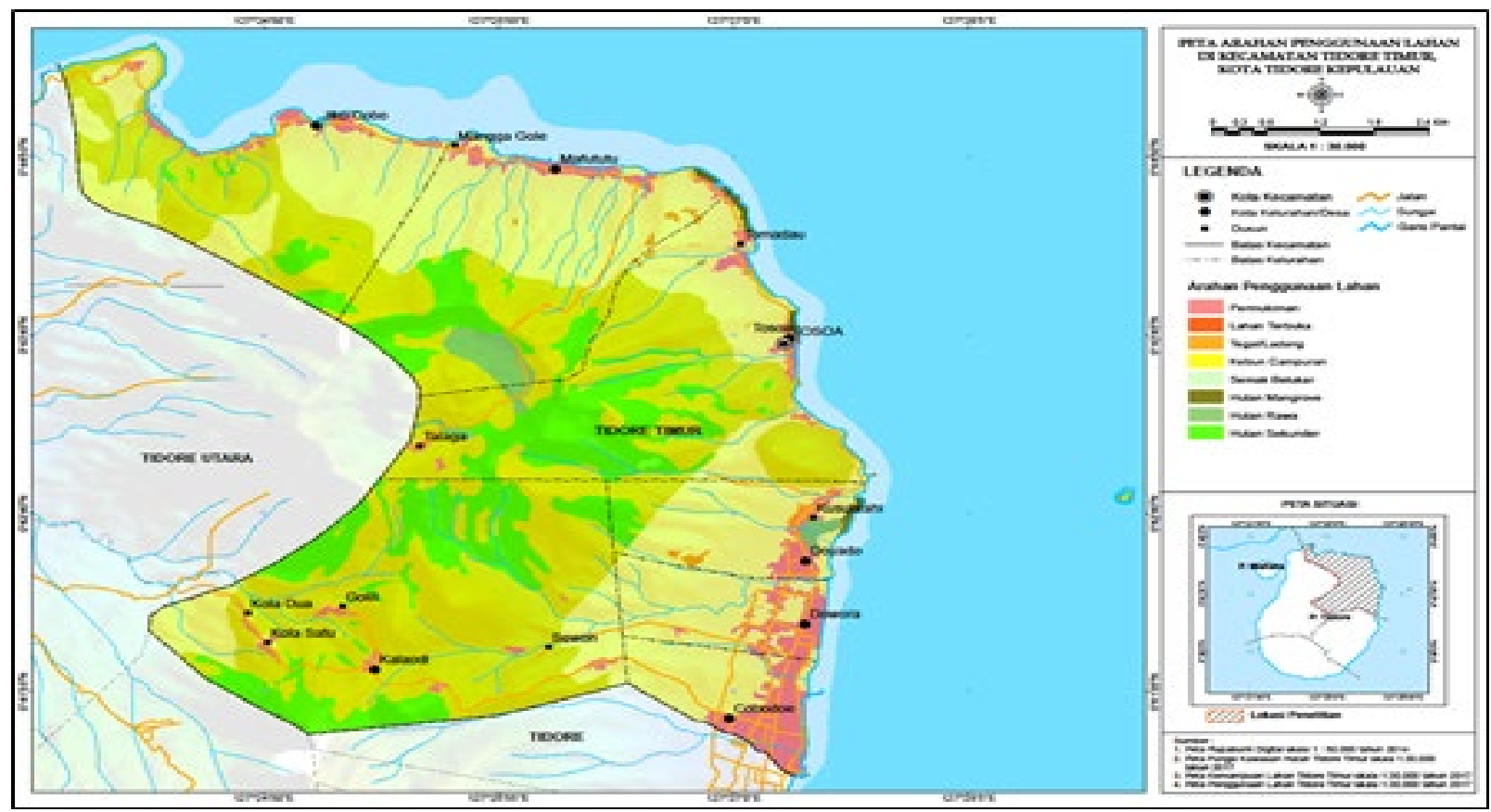

Figure 3. Map of Land Use Directive in East Tidore Subdistrict 
Table 4. Value of agricultural crops and livestock production in East Tidore Subdistrict

\begin{tabular}{|c|c|c|c|c|c|}
\hline \multirow{2}{*}{ No } & \multirow{2}{*}{ Commodity } & \multicolumn{2}{|c|}{ Production } & \multirow{2}{*}{$\begin{array}{c}\text { Unit Price } \\
\mathrm{Rp} / \mathrm{kg}\end{array}$} & \multirow{2}{*}{$\begin{array}{c}\text { Production Value } \\
\text { Rp }\end{array}$} \\
\hline & & ton & kg & & \\
\hline 1 & Corn & 1.4 & 1,400 & 5,000 & $7,000,000$ \\
\hline 2 & Cassava & 20 & 20,000 & 10,000 & $200,000,000$ \\
\hline 3 & Shallot & 3.4 & 3,400 & 45,000 & $153,000,000$ \\
\hline 4 & Cucumber & 70 & 70,000 & 10,000 & $700,000,000$ \\
\hline 5 & Long beans & 40 & 40,000 & 15,000 & $600,000,000$ \\
\hline 6 & Chili & 51 & 51,000 & 40,000 & $2,040,000,000$ \\
\hline 7 & Eggplant & 26.5 & 26,500 & 10,000 & $265,000,000$ \\
\hline 8 & Mustard/Chinese cabbage & 2.35 & 2,350 & 15,000 & $35,250,000$ \\
\hline 9 & Rambutan & 2.7 & 2,700 & 15,000 & $40,500,000$ \\
\hline 10 & Durian & 1010 & $1,010,000$ & 25,000 & $25,250,000,000$ \\
\hline 11 & Banana & 123 & 123,000 & 10,000 & $1,230,000,000$ \\
\hline 12 & Breadfruit & 2.2 & 2,200 & 15,000 & $33,000,000$ \\
\hline 13 & Mango & 322.7 & 322,700 & 10,000 & $3,227,000,000$ \\
\hline 14 & Papaya & 0.8 & 800 & 10,000 & $8,000,000$ \\
\hline 15 & Jackfruit & 13.7 & 13,700 & 25,000 & $342,500,000$ \\
\hline 16 & Coconut & 18 & 18,000 & 8,000 & $144,000,000$ \\
\hline 17 & Clove & 111 & 111,000 & 90,000 & $9,990,000,000$ \\
\hline 18 & Nutmeg & 36 & 36,000 & 55,000 & $1,980,000,000$ \\
\hline 19 & Beef product & 1.14 & 1,140 & 130,000 & $148,200,000$ \\
\hline 20 & Goat meat production & 0.192 & 192 & 100,000 & $19,200,000$ \\
\hline 21 & Broiler production & 81.6 & 81,600 & 35,000 & $2,856,000,000$ \\
\hline 22 & Production of free-range eggs & 20.156 & 20,156 & 25,000 & $503,900,000$ \\
\hline 23 & Production of Duck Eggs & 1.132 & 1,132 & 15,000 & $16,980,000$ \\
\hline \multicolumn{5}{|c|}{ Total Value } & $49,789,530,000$ \\
\hline
\end{tabular}

Table 5. Land use composition in East Tidore Subdistrict

\begin{tabular}{|c|c|c|c|c|}
\hline \multirow{2}{*}{ No } & \multirow{2}{*}{ Land Use Directive } & \multirow{2}{*}{$\begin{array}{c}\text { Existing area } \\
\text { (ha) }\end{array}$} & \multicolumn{2}{|c|}{ Landing Area } \\
\hline & & & Ha & $\%$ \\
\hline 1 & Settlement & 191.8 & 191.8 & 6.4 \\
\hline 2 & Moor/Field & 53.2 & 7.8 & 0.3 \\
\hline 3 & Mixed Garden & $2,036.5$ & $1,058.7$ & 35.1 \\
\hline 4 & Agroforestry & - & $1,233.6$ & 40.9 \\
\hline 5 & Mangrove forest & 10.8 & 11.4 & 0.4 \\
\hline 6 & Swamp Forest & 32.3 & 45.6 & 1.5 \\
\hline 7 & Secondary Forest & 348.0 & 470.4 & 15.6 \\
\hline \multicolumn{3}{|c|}{ Total } & $3,019.2$ & 100.0 \\
\hline
\end{tabular}

The area of land needed for decent living needs per resident (KHLL) is the need for decent living per resident (assumed $1,000 \mathrm{~kg} /$ per capita/year) divided by local rice productivity $(1,418 \mathrm{~kg} / \mathrm{ha})$ obtained per capita land requirement of 0.7 capita/ha.

Based on the data analysis above shows the availability of land (SL) of 2,926 ha while the need for land equivalent to rice (DL) in 2016 amounted to 6,420 ha and in 2026 amounted to 7,919 ha. Land needs both at present (2016) and the next 10 years (2026) have exceeded the carrying capacity of available land in East Tidore Subdistrict which is only available at 2,926 ha.

\section{E. Land Use Directive}

The land use direction in East Tidore Subdistrict is based on the results of the analysis of land capability, existing land use, land use suitability and forest area function, the composition of land use in East Tidore Subdistrict is presented in Table 5.

Land use guidance (Table 5) obtained total land for agricultural development covering 2,300.1 ha (76.2\%) 
consisting of land use/land area of 7.8 ha $(0.3 \%)$, mixed garden covering $1,058.7$ ha $(35.1 \%)$ and agroforestry covering $1,233.6$ ha $(40.9 \%)$. Spatial availability of land for agriculture which is $2,300.1$ ha $(76.2 \%)$ has not been able to meet the needs of land in the Subdistrict of East Tidore which is an area of 6,420 ha, even the total area of East Tidore Subdistrict (3,019.2 ha) also cannot meet the existing land needs. Spatially directed land use maps in East Tidore Subdistrict are presented in Figure 3.

\section{CONCLUSION}

1. There are six land capability classes, namely class III covering 650.2 ha $(21.5 \%)$, class IV covering $1,060.8$ ha $(35.1 \%)$, class V covering 47.2 ha $(1.6 \%)$, class VI covering an area of 454.1 ha $(15.0 \%)$, class VII covering an area of 325.7 ha $(10.8 \%)$ and class VIII covering an area of 481.2 ha $(15.9 \%)$.

2. Land capability classes suitable for agricultural development (classes III and IV) cover 1,711.0 ha (56.7\%) and unsuitable (classes V, VI, VII and VIII) of $1,308.2$ ha $(43.3 \%)$.

3. The use of existing agricultural plantations/mixed estates that are in accordance with the capability of land (class III and IV) covering 1,176.4 ha (39.0\%) and not suitable (class V, VI, VII and VIII) covering 860.1 ha $(28.5 \%)$, and the use of suitable moor/land area of 24.3 ha $(0.8 \%)$ and unsuitable area of 28.9 ha $(1.0 \%)$.

4. The availability of land (SL) covers an area of 2,926 ha and the need for land equivalent to rice (DL) is 6,420 ha, where the land requirement has exceeded the carrying capacity of the land contained in East Tidore Subdistrict.

5. The direction of land use for agricultural development in the Subdistrict of East Tidore covering an area of $2,300.1$ ha $(76.2 \%)$ consisting of the use of moor/land area of 7.8 ha $(0.3 \%)$, mixed gardens covering $1,058.7$ ha $(35.1 \%)$ and agroforestry covering 1,233.6 ha $(40.9 \%)$

\section{REFERENCES}

[1] Dumanski, J, Bindraban, P. S, Pettapiece, W. W, Bullock, P, Jones, R. J. A, \& Thomasson, A. (2010). Land classification, sustainable land management, and ecosystem health. Interdisciplinary and Sustainability Issues in Food and Agriculture, 3, 244266.

[2] Mohana, P., Mariappan, N. V. E., \& Manoharan, N. (2009). Land suitability analysis for the part of Parambikulam Aliyar command area, Udumalpet Taluk using remote sensing and GIS techniques. International Journal on Design and Manufacturing
Technologies, $\quad 3 \quad$ (2), 98-102. doi:10.18000/ijodam.70069

[3] Gebrehana Girmay, Workat Sebnie \& Yonas Reda Manuel Tejada Moral (Reviewing editor) (2018) Land capability classification and suitability assessment for selected crops in Gateno watershed, Ethiopia, Cogent Food \&Agriculture,4:1, DOI: $10.1080 / 23311932.2018 .153$ $\underline{2863}$

[4] Verheye, W. (2008). Land evaluation. In Land use and Land Cover (II). Belgium: UNESCO-EOLSS, Ghent University Library.

[5] Suripin. 2004. Pelestarian Sumberdaya Tanah dan Air. Penerbit ANDI Yogyakarta.

[6] Arsyad S. 2010. Konservasi Tanah dan Air. IPB Press. Bogor.

[7] AbdelRahman, M. A. E., Natarajan, A., \& Hegde, R. (2016). Assessment of land suitability and capability by integrating remote sensing and GIS for agriculture in Chamarajanagar district, Karnataka, India. The Egyptian Journal of Remote Sensing and Space, 19(1), 125-141

[8] Mu, Y. (2006). Developing a suitability index for residential land use: A case study in Dianchi drainage area. Canada: University of Waterloo.

[9] Bizuwerk, A., Peden, D., Taddese, G., \& Getahun, Y. (2005). GIS application for analysis of land suitability and determination of grazing pressure in upland of the Awash River Basin, Ethiopia. Addis Ababa, Ethiopia: International Livestock Research Institute (ILRI)

[10] Pan, G., \& Pan, J. (2011, October). Research in crop land suitability analysis based on GIS. In International Conference on Computer and Computing Technologies in Agriculture (pp. 314325). Springer, Berlin, Heidelberg.

[11] Peraturan Menteri Negara Lingkungan Hidup Nomor 17 Tahun 2009 tentang Pedoman Penentuan Daya Dukung Lingkungan Hidup dalam Penataan Ruang Wilayah. Ditetapkan di Jakarta pada Tanggal : 22 Mei 2009

[12] Hardjowigeno S, Widiatmaka. 2007. Kesesuaian Lahan dan Perencanaan Tataguna Tanah. Institut Pertanian Bogor.

[13] Handoko. 1993. Klimatologi Dasar. Jurusan Geofisika dan Meteorologi Institut Pertanian Bogor. Bogor.

[14] Soil Survey Staff, 2014. Key To Soil Taxonomy $12^{\text {th }}$ Edition. United States Department of Agriculture.

[15] PPT (Pusat Penelitian Tanah), 2016 Petunjuk Teknis Klasifikasi Tanah Nasinal Edisi 2, Badan Penelitian dan Pengembangan Pertanian. Kementrian Pertanian. 